\title{
Innovation of The Practice Teaching Method into The Process of Ideological and Political Theory Course Teaching
}

\author{
Yong Liu \\ Department of Politics \\ Yangzhou University, 225009 \\ Yangzhou, China
}

\begin{abstract}
Practice teaching is an important form of Ideological and political theory course teaching, not only embodies the theory with the practice of the fundamental principle, but also to promote ideological and political theory course content "Internalization" as the fundamental way of College Students' Ideological and political quality, ideological and political theory courses to stimulate interest in learning and initiative, to help college students social practice through the formation of science world outlook, outlook on life and values has important significance. At present, the teaching practice of Ideological and political theory course in our country still exist many problems, the fundamental path to solve these problems is to regulate and promote the construction of practice teaching, new form, continue to expand the teaching of Ideological and political theory course practice.
\end{abstract}

Keywords-practice teaching method; ideological and political theory course; theoretical basis; main problems; countermeasures and suggestions

\section{INTRODUCTION}

The ideological and political theory course is the main content education and teaching of Marx's theory of education and ideological and political education, in order to strengthen and improve the ideological and political theory course teaching reform practice, must be introduced into the teaching of Ideological and political theory course teaching, improve the ideological and Political Theory Course Teaching effect and teaching quality. The practice of teaching, is according to the teaching contents of Ideological and political theory courses, will be included in the teaching plan of Ideological and political theory course teaching syllabus, teaching content as the theme, in the guidance of Ideological and political theory course teachers, the students give full play to the role of subjectivity of Ideological and political theory course teaching, through investigation and research, scientific experiments, visit access and other forms, students learn knowledge of Marx's theory of the research, training, participation, interaction, improve the social practice ability, enhance the ability of comprehensive quality, establishing and perfecting the world view, values, outlook on life. The social practice teaching mode with its participation degree is high, the form of lively, interactive, lively and can inject vitality to the teaching, improve students' interest in learning, plays a very important role in the ideological and political theory courses.

\section{THE IDEOLOGICAL BASIS OF PRACTICE TEACHING METHOD INTO THE IDEOLOGICAL AND POLITICAL THEORY COURSE TEACHING}

Ideological and political theory course in essence is the theoretical education and practical education, the unity of theory and practice is the basic principle of Ideological and political theory course teaching, which has become the most fundamental theory of Ideological and political theory course teaching. As we know, the ideological and political theory course practice teaching for cultivating the application of theoretical knowledge, students will learn to practice plays an important role, through social practice, students can apply the theory to observe the society, social analysis, think about life, enlightenment. Therefore, the practice teaching is an important link of Ideological and political theory course teaching. The practice teaching of Ideological and political theory has two broad and narrow sense, broad practice refers to the social practice, narrow practice includes classroom practice, scientific research practice, experience and other forms. In the course of Ideological and political theory, practice generally refers to the investigation, experiment, practice, social practice. The elucidation of the function and value of practice teaching in Ideological and political theory teaching in theory, is of great significance to carry out practice teaching.

Role of teaching in the ideological and political theory courses and practical value, the first performance in practical teaching is the embodiment of theory with practice, but also to promote the ideological and political theory, theory of moral and legal theory of "Internalization" as the fundamental way of College Students' Ideological and political quality, is also the student learning, master, important process understanding and use of the ideological and political theory the. The basic orientation of College Ideological and political theory course is armed with scientific theory of mind of college students, it is necessary for the Marx theory, ideological and moral concepts, legal consciousness "in the classroom, teaching materials", but this is only the external inculcation, ideological and political theory course must also be Marx 
theory, ideological and moral concepts legal consciousness, "mind", this is the ideological and political theory course fundamental purpose, achieve this one witness, whose essence is the theory of "internalization". Theory comes from practice, only in practice can be a real theory, enhance understanding, practice is the decisive influence on the theory and knowledge. From this perspective, the practice is an important part of the theory of "Internalization" process, is also the necessary link of Ideological and political education, classroom learning theory only through the way of social practice can truly "Internalization" for college students' Ideological and political quality, become college students ideal and belief.

The practice teaching of Ideological and political theory course is another important theory is based on practice teaching, to stimulate students interest in learning of Ideological and political theory course, mobilize the initiative consciousness of college students in Ideological and political theory course, make students form has an important significance in understanding of the social reality of rational through social practice. At present, the socialist education China characteristics is an important content of Ideological and political theory course teaching, the great cause of college students only in-depth China characteristic socialism, deepen their understanding of society, understanding of the masses of the people, in order to accurately grasp the situation, a comprehensive understanding of the socialist construction and the development law, enhance the China characteristic socialist road self-confidence, self-confidence and confidence theory system, form the theory China socialist cognition more lasting reason.

The theoretical basis of practice teaching in Ideological and political theory course is a teaching method to link theory with practice, to avoid the disadvantages of the traditional teaching theory divorced from practice, improve the ideological and political theory course teaching effect, put into Marx theory teaching colorful socialist society Chinese feature of life and social practice of College Students Social practice of college students, is to implement the passage through the principle of integrating theory with practice. At the same time, the practice teaching and improve the students' abilities of analyzing and solving problems, to improve the comprehensive quality of university students has important significance. The practice teaching of Ideological and political theory courses, through social practice, students accumulate ability to know the society, proposed the question, analysis contradictions, to give suggestions, not only improving the comprehensive quality of students, also created their sound perfect personality, these positive effects are difficult to achieve in the classroom teaching, practice teaching an important supplement to the teaching of Ideological and political theory course teaching.

\section{THE OUTSTANDING PROBLEMS OF PRACTICE TEACHING METHOD INTO THE IDEOLOGICAL AND POLITICAL THEORY COURSE TEACHING}

Although the practical teaching plays an important role in Ideological and political theory course, also welcome by both teachers and students, but there are still a lot of problems in the concrete operation, these problems directly restricts the practice teaching play an active role in Ideological and political theory, not only affects the students' interest in the ideological and political theory course, also affected the thought the political theory course teaching effect and teaching quality. At present, the main problems existing in the practice teaching:

Firstly, the practice teaching is not simply to implement the principle of integrating theory with practice, but the theory and practice of detachment, restricting the practice teaching effect, also affect the ideological and political theory course teaching effect. The theoretical basis of teaching theory and practice is not only practical, but also the fundamental principle of Ideological and political theory course teaching. Practice is the starting point of the theory of the Marx doctrine, the practice is the basic characteristics of Marx's theory. In Marx's theory as the main content of the ideological and political theory course should be practical principle. However, the ideological and political theory course most of the traditional indoctrination, lack of participation and practice of students, causes the ideological and political theory course teaching effect. Therefore, the lack of the practical teaching of Ideological and political theory course is difficult to ensure the effectiveness of teaching, the classroom teaching and practice teaching, to integrate theory with practice, to understand the theory, summed up the law, improve the ideological and political quality in the social practice, ideological and political theory course teaching effect will continue to improve.

Secondly, because of the lack of teaching concept, teaching funds, teaching organization, ideological and political theory course teaching practice to ensure adequate teaching resources, which include teaching funds insufficient, lack of teaching hours, teaching base construction cannot guarantee. Practice teaching must have the human, material and financial resources, guarantee, through increased investment funds practice teaching, renew the teaching concept, paying attention to the positive effect of practice teaching in Ideological and political theory course, keep the practice teaching hour arrangement, the students from the classroom lead to society, continue to understand society, into the society, probes into the reality, thorough basic level, in practice study of realistic problems, understand the scientific theory, and continuously enhance the capacity for independent understanding students' independent study and. But, in reality, many colleges and universities, to the school leaders, the practice of teaching the course of Ideological and political theory course teacher or down to the insufficient funds, reluctant, unwilling to spend time, reluctant to focus on teaching practice of the organization work, leading to the practice teaching effect of Ideological and Political Theory course is not good. These problems, problems with teaching base is not enough, resulting in the social practice of college students only in the school to carry out; the teachers strength weak, leading to lack of practice teaching organization and coordination of unified standards. Practice teaching to improve the ideological and political theory course must school leaders and all participants have great enthusiasm and advanced teaching idea, strengthening practice teaching input, earnestly practice teaching design scheme and process, 
standardized operation, the establishment of a social practice base for the students, full play to the role of practice teaching in Ideological and Political Theory course.

Thirdly, the practice teaching in ideological and political theory courses in more casual, the lack of scientific management and reasonable standard, leading to the practice of Ideological and political theory course teaching large arbitrariness. Ideological and political theory course is a system engineering, it involves to the students themselves, teachers of Ideological and political theory, office of academic affairs, student office, the Propaganda Department, the Communist Youth League and other relevant individuals and units. Based on this, the management mechanism of practice teaching of Ideological and political theory must have a scientific, standardized and the implementation rules, especially the educational departments should co-ordinate school departments, the coordination of all people to participate in the social practice of college students work, the establishment of College Students' practical teaching and improve the management system, ensure the practice teaching of Ideological and political theory course the material and financial resources, manpower support, to undertake the practice teaching in Ideological and political theory course in departments of tasks and division of labor should be clearly defined. Cooperate and coordinate with only the ideological and political theory teachers and schools in various administrative departments, in order to effectively carry out the practice teaching.

\section{COUNTERMEASURES OF PRACTICE TEACHING METHOD INTO THE IDEOLOGICAL AND POLITICAL THEORY COURSE TEACHING}

Practice teaching is an important way and means of Ideological and political theory course teaching, has very important significance for improving the quality of teaching and the teaching effect of Ideological and political theory course, also plays an important role in the development of the college students. Promotion of practical teaching in Ideological and political education in the new period, should be from the following aspects:

On the one hand, to the practice of teaching the course of Ideological and political theory of standardization construction, establish a set of effective teaching theory system and method system, improve the effectiveness of practice teaching in Ideological and political theory courses in and the. The main four aspects of the problem involved here: one is to update the educational concept, practice as the basic principle of education, the practice teaching as the basic approach to the ideological and political theory course, cultivating students' world outlook, outlook on life, values in practice; two is set up to promote ideological and political theory course practice the teaching of professional organizations, the establishment of the committee responsible for the practice teaching, practice teaching plan, curriculum setting, organization and implementation, assessment work, promote the ideological and political theory course practice teaching with scientific, systematic, institutionalized, standardized requirements; three is to give the practice of Ideological and Political Theory course of human, material, teaching enough financial support, especially given enough practice teaching credits and hours, ensure the high quality of practice teaching.

On the other hand, new form, new ways of expanding the thought politics theory class practice teaching, the classroom practice, practice, practice, practice, practice holiday form and combining, the teacher as guide, students as the main body, in practice growth. At the same time, should set up the practical teaching base fixed, such as the old revolutionary base areas, industrial district, cultural attractions are the base to carry out ideological and political theory practice teaching is very good. At the same time, but also by the practice of teaching and volunteer activities, community service, occupation training, part-time, volunteer labor and other forms, in the social investigation, investigation, research, rural enterprise factory study further the study and understanding of the Marx doctrine. On this basis, should also be different according to the students, the different professional and individualized teaching, combined with the interest of students in teaching practice. In the teaching environment, the social practice from the classroom to the community, to factories, to the community, an important place of the ideological and political theory course practice teaching network also is the new period, strengthen college students in the practice of education of network society, the network coverage to the field practice teaching.

\section{REFERENCES}

[1] Chen Wanbai, Zhang Yaocan: principle of Ideological and political education, higher education press, 2007.

[2] Zhang Yaocan: 30 years of reform and opening up integration development of Ideological and political education, volume first, 2009 edition of Herald of Ideological and theoretical education. 